\title{
Does Central Serotonin2C Receptor still have New Therapeutic Potential?
} Giuseppe Di Giovanni*

Department of Physiology \& Biochemistry, Faculty of Medicine and Surgery, University of Malta, Malta

Keywords: Serotonergic receptors; Depression; Schizophrenia; Drug of abuse; Epilepsy; selective $5-\mathrm{HT}_{2 \mathrm{C}}$ drugs

Since the 1950s, when serotonin (5-HT) was discovered in the mammalian central nervous system (CNS), an enormous amount of experimental evidence has revealed the pivotal role of this biogenic amine in a number of cognitive and behavioural functions [1]. Although 5 -HT is synthesized by a small group of neurons within the raphe nuclei of the brain stem, almost all parts of the CNS receive serotonergic projections. Furthermore, the importance of 5-HT modulation and the fine-tuning of its action are underlined by the large number of 5-HT binding sites found in the CNS. Hitherto, up to 15 different 5-HT receptors subtypes have been identified [2]. Large amounts of experimental evidence have explored the pathophysiological role of one of these receptors, the $5-\mathrm{HT}_{2 \mathrm{C}}$ receptor, that has emerged as a prominent central serotonin receptor subtype [3]. Indeed, since its discovery about 25 years ago by Palacios, Pazos and Hoyer, who named it 5-HT1C [4] (see the book 5-HT2C Receptors in the Pathophysiology of CNS disease, 2011); it has been shown to play a major role in the regulation of a plethora of behaviours. Therefore, it is not surprising that experimental and clinical observations have highlighted it as a possible therapeutic target for the development of drugs for a range of CNS disorders such as schizophrenia, depression, drug abuse, eating disorders, Parkinson's disease and epilepsy, to cite but a few [5-10]. Thus, the 5-HT2C antagonism appears to be an important feature of antipsychotic and antidepressants drugs with broad pharmacological profiles, properties that probably contribute to the treatment of negative and depressive symptoms respectively, or to the mitigation of side-effects. Although several selective agents for this receptor have been discovered, none have reached the market for the treatment of CNS disorders to date, essentially as a result of their limited efficacy and related side effects. Indeed, most of the 5-HT2C ligands have binding affinity for the 5 -HT2B receptors, which may limit its therapeutic potential given that action at peripheral 5-HT2B receptors is thought to underlie the cardiopulmonary complications associated with some serotonergic drugs [11]. Several pharmaceutical companies are still very active in 5-HT2C receptors research. Nevertheless, the only compound with 5-HT2C affinity that has reached the market is agomelatine, released by Servier for the treatment of major depressive disorder with a reduced level of sexual side effects compared to some other antidepressants. Agomelatine is a melatonergic agonist (MT1 and MT2 receptors) and 5-HT2C antagonist [12]. Probably the next 5-HT2C compound to obtain the Food and Drug Administration (FDA) approval in the United States will be lorcaserin by Arena Pharmaceuticals, for the treatment of obesity [13]. Lorcaserin shows 100 times higher affinity for 5-HT2C versus other receptors, the only drawback is the exposure-response relationship for lorcaserin-emergent mammary adenocarcinoma. However, given the results of the Pathology Working Group, this may no longer be of concern since there is no statistically significant increase in mammary risk for lorcaserin patients. Therefore there is good chance for lorcaserin to gain the FDA approval later on during this year.

There are also many avenues that remain unexplored, so there are undoubtedly further advances to be made. For example, we are currently carrying out some experiments on the effect of 5-HT2C ligands in different models of epilepsy both generalised and focal seizures and we have obtained very promising results. Our preliminary data show that agonists for the 5-HT2C receptors have a potent antiepileptic action. These findings are in agreement with the well known activity of 5-HT2C receptor signal in controlling cell excitability [14]. Indeed, mice knock out for this receptor have higher rate of mortality and the survived ones show an increased susceptibility to seizures [14-17]. Although the available compelling evidence for the role of 5-HT2C receptors in epileptogenesis and/or propagation, no drugs are currently under development by pharmaceutical companies. This reflects a general situation of lack of investment by the pharmaceutical industry in research for CNS diseases, especially for epilepsy. Even in highincome countries, epilepsy has suffered historical neglect and despite high costs and severe disabling effects, epilepsy may attract somewhat less research funding from public and private sources than other less common chronic neurological disorders. To bring to the market new drugs, the relation between the epilepsy community and pharmaceutical companies must change. Indeed, governments should understand that basic and clinical academic epilepsy research particularly needs independent support to overcome the natural tendency of the drug industry to prefer markets with a larger monetary value. Therefore, increasing funding for public laboratories is of paramount importance.

Nevertheless, I am hopeful that in the next few years, we certainly will see new compounds selective for 5-HT2C receptors, making further significant impacts on the treatment of the major neuropsychiatric disturbances, including epilepsy. In conclusion, it is apparent that 5-HT2C receptors still offer therapeutic potential, even those not yet discovered.

\section{References}

1. Di Giovanni G, Esposito E, Di Matteo V (2010) Role of serotonin in central dopamine dysfunction. CNS Neurosci Ther 16: 179-194.

2. Hoyer D, Clarke DE, Fozard JR, Hartig PR, Martin GR, et al. (1994) International Union of Pharmacology classification of receptors for 5-hydroxytryptamine (Serotonin). Pharmacol Rev 46: 157-203.

3. Di Giovanni G, Di Matteo V, Pierucci M, Benigno A, Esposito E (2006) Centra serotonin2C receptor: from physiology to pathology. Curr Top Med Chem 6 : 1909-1925.

4. Hoyer D, Pazos A, Probst A, Palacios JM (1986) Serotonin receptors in the human brain II Characterization and autoradiographic localization of 5-HT1C and 5-HT2 recognition sites. Brain Res 376: 97-107.

5. Wacker DA, Miller KJ (2008) Agonists of the serotonin 5-HT2C receptor: preclinical and clinical progression in multiple diseases. Curr Opin Drug Discov Devel 11: 438-445.

*Corresponding author: Prof. Giuseppe Di Giovanni, Department of Physiology and Biochemistry, University of Malta, Msida MSD 2080, Malta, Tel: +356 23402776; Fax: +356 21310577; E-mail: giuseppe.digiovanni@um.edu.mt

Received March 23, 2012; Accepted March 25, 2012; Published March 28, 2012

Citation: Giovanni GD (2012) Does Central Serotonin2C Receptor still have New Therapeutic Potential? Biochem Physiol 1:e101. doi:10.4172/2168-9652.1000e101

Copyright: @ 2012 Giovanni GD. This is an open-access article distributed under the terms of the Creative Commons Attribution License, which permits unrestricted use, distribution, and reproduction in any medium, provided the original author and source are credited. 
Citation: Giovanni GD (2012) Does Central Serotonin2C Receptor still have New Therapeutic Potential? Biochem Physiol 1:e101. doi:10.4172/21689652.1000e101

Page 2 of 2

6. Monck NJ, Kennett GA (2008) 5-HT2C ligands: recent progress. Prog Med Chem 46: 281-390

7. Rosenzweig-Lipson S, Dunlop J, Marquis KL (2007) 5-HT2C receptor agonists as an innovative approach for psychiatric disorders. Drug News Perspect 20: $565-571$

8. Kostrzewa RM, Huang NY, Kostrzewa JP, Nowak P, Brus R (2007) Modeling tardive dyskinesia: predictive $5-\mathrm{HT} 2 \mathrm{C}$ receptor antagonist treatment. Neurotox Res 11: 41-50.

9. Di Giovanni G, Di Matteo V, Pierucci M, Benigno A, Esposito E (2006) Serotonin involvement in the basal ganglia pathophysiology: could the $5-\mathrm{HT} 2 \mathrm{C}$ receptor be a new target for therapeutic strategies? Curr Med Chem 13: 3069-3081.

10. Bubar MJ, Cunningham KA (2006) Serotonin 5-HT2A and 5-HT2C receptors as potential targets for modulation of psychostimulant use and dependence. Curr Top Med Chem 6: 1971-1985.

11. Fitzgerald LW, Burn TC, Brown BS, Patterson JP, Corjay MH, et al. (2000) Possible role of valvular serotonin $5-\mathrm{HT}(2 \mathrm{~B})$ receptors in the cardiopathy associated with fenfluramine. Mol Pharmacol 57: 75-81.
12. Millan MJ, Marin P, Kamal M, Jockers R, Chanrion B, et al. (2011) The melatonergic agonist and clinically active antidepressant agomelatine is a neutral antagonist at $5-\mathrm{HT}(2 \mathrm{C})$ receptors. Int J Neuropsychopharmacol 14 768-783.

13. Fidler MC, Sanchez M, Raether B, Weissman NJ, Smith SR, et al. (2011) A one-year randomized trial of lorcaserin for weight loss in obese and overweight adults: the BLOSSOM trial. J Clin Endocrinol Metab 96: 3067-3077.

14. Tecott LH, Sun LM, Akana SF, Strack AM, Lowenstein DH, et al. (2007) Eating disorder and epilepsy in mice lacking $5-\mathrm{HT} 2 \mathrm{c}$ serotonin receptors. Nature 374 542-546.

15. Heisler LK, Chu HM, Tecott LH (1998) Epilepsy and obesity in serotonin 5-HT2C receptor mutant mice. Ann N Y Acad Sci 861: 74-78.

16. Applegate CD, Tecott LH (1998) Global increases in seizure susceptibility in mice lacking 5-HT2C receptors: a behavioral analysis. Exp Neurol 154: 522 530

17. Brennan TJ, Seeley WW, Kilgard M, Schreiner CE, Tecott LH (1997) Sound induced seizures in serotonin $5-\mathrm{HT} 2 \mathrm{c}$ receptor mutant mice. Nat Genet 16 : 387-390.
Submit your next manuscript and get advantages of OMICS Group submissions

Unique features:

User friendly/feasible website-translation of your paper to 50 world's leading languages

Audio Version of published paper

Digital articles to share and explore

Special features:

200 Open Access Journals

15,000 editorial team

21 days rapid review process

Quality and quick editorial, review and publication processing

- Indexing at PubMed (partial), Scopus, DOAJ, EBSCO, Index Copernicus and Google Scholar etc

- Sharing Option: Social Networking Enabled

- Authors, Reviewers and Editors rewarded with online Scientific Credits

Befter discount for your subsequent articles

Submit your manuscript at: http://www.omicsonline.org/submission 